\title{
SPRING MOTHS, AND HOW TO CATCH THEM.
}

BY E. J. SMITH, NATICK, MASS.

THE moths of spring may be taken in three different ways. First, by going out at night with a lantern, and examining the blossoms of the "pussy willow"; second, by tapping trees (especially sugar maples) and examining them by lantern light; and thirdly, by the use of a trap lantern. The first two methods are of use only for a short time in spring, but the last is equally good during the whole season. The early moths are mostly too sluggish to come to light in any numbers, but are attracted to willow blooms, and to the fresh sap of maple or birch trees in quantities; they will not fly away when disturbed, but will let go their hold and drop quietly into a jar or box held beneath them.

When feeding on sap the moths will often drop to the ground and feign death if the light of the lantern strikes them, and if there is any grass at the foot of the tree they are very hard to find. To avoid this difficulty, and turn the habit of the moths to my advantage, I take a hoe and scrape the ground bare for a space of two feet or more around the base of the tree, and beat it down smooth and hard. Then when the moths drop they are very easily seen, and can be picked up with forceps and dropped into a cyanide jar.

The moths which come to maple sap begin to fly very early in spring, usually by the third week in March if the weather is mild. The principal ones to be got in this way are species of Xylina, Calocampa, and Scopelosoma; occasionally one finds also Pachnobia salicarum, Taeniocampa alia, and Jodia rufago. Afterward the same species are to be found on the willow blossoms, together with Taeniocampa subterminata, Homoglaea hircina, Nyctobia fusifasciata, and others.

A little later the trap lantern will give the best results. In Entomological News for September, 1902, I gave a description of my lantern and method of using it, and Mr. Slingerland has given a very interesting account of his experience with trap lanterns in Bulletin 202 of Cornell University Agricultural Experiment Station. Briefly described, the lantern I use is a square box of wood with sides of glass, having top and smoke pipe similar to the old style street lanterns, and having holes at the bottom for ingress of air. The box must be large enough to contain an ordinary kerosene lamp with chimney, and is to be supported over a zinc lined wooden box about 16 inches square and 3 inches deep. In this latter box I place water and kerosene in equal parts, to a depth of about two inches. I obtain better results with such a combination than with the slight film of oil usually employed. 
The moths fly to the light, and on striking the glass drop into the kerosene and sink as far as the water, where they float, and are thus out of the way of the next comers. The water keeps them out of contact with any dirt which may be at the bottom. In the morning I take the moths out by the legs with a pair of finepointed forceps, lay them on several thicknesses of old newspaper in the bottom of a good-sized pasteboard box, and leave them for a few hours to get rid of the bulk of the oil; then soak them in gasolene for several hours. When removed from the gasolene and laid on blotting paper to dry they soon appear as fresh and clean as though never wet. I have taken in this way about five hundred species. Below is a list of those taken during the spring months.

March 30.

Homoglaea hircina.

April : first half.

Copipanolis cubilis, Eutolype rolandi, Psaphidia resumens, Pachnobia salicarum, Calocampa nupera, Nyctobia fusifasciata, Paleacrita vernata, Phigalia titea, Xylina and Scopelosoma, several species.

April : second half.

Calocampa curvimacula, Drasteria, 2 species, Lycia ursaria, Eutrapela alciphearia, Azelina peplaria, Abbotana clemataria, Celama triquetrana.

May : first half.

Apatela xyliniformis, A. oblinita, Crocigrapha normani, Phoberia atomaris, Ypsia undularis, Melalopha albosigma, Mesoleuca intermediata, Orthofidonia vestaliata, Homochlodes fritillaria, Anagoga occiduaria, Plagodis keutzingi, Hyperitis amicaria, Metanema quercivoraria.

May : second half.

Deidamia inscriptum, Sphinx gordius, Automeris io, Estigmene acraea, E. congrua, Isia isabella, Diacrisia virginica, Apantesis virguncula, $A$. rectilinea, $A$. arge, A. phyllira, A. phalerata, Arsilonche albovenosa, Balsa malana, Caradrina miranda, Hyppa xylinoides, Euplexia lucipara, Actinotia ramosula, Feltia volubilis, Mamestra detracta, M. grandis, $M$. rosea, Ulolonche modesta, Heliophila luteopallens, $H$. albilinea, H. multilinea, Graphiphora oviducta, Gortyna u-album, Euthisanotia unio, Autographa simplex, Abrostola urentis, Ogaloconta cinereola, Marasmalus ventilator, Eustrotia concinnimacula, Tarache candefacta, Euparthenos nubilis, Parallelia bistri. 
aris, Zale horrida, Ypsia aeruginosa, Homoptera unilineata, Melalopha inclusa, Nerice bidentata, Schizura unicornis, Eudeilinea herminiata, Drepana arcuata, Falcaria bilineata, Eucymatoge intestinata, Euchoeca cretaceata, Hydriomena multiferata, Cosymbia lumenaria, Chlorochlamys chloroleucaria, Aplodes mimosaria, A. rubrifrontaria, Deilinea variolaria, Sciagraphia heliothidata, Lycia cognataria, Gonodontis duaria, G. obfirmaria, Euchlaena marginata, Metanema textrinaria.

[Mr. Smith's collecting is done at his home in Sherborn, Mass., near the Natick line. The locality is in a farming community (street-lights absent) and presents the usual diversity of environment characteristic of the sand-plain area of eastern Massachusetts :orchards, fields, gardens and shade-trees; gravelly plains and ridges sloping down into sedgy meadows through which .wind sluggish, alder-fringed streams; peat-bogs, bushy swamps, and woodlands consisting now chiefly of a young growth of deciduous trees but formerly containing large tracts of white pine. The elevation is about $\mathrm{I}$ 7o feet, dropping to 140 at the streams, and rising to 260 or even 400 at distances of half a mile to a mile and a half in boulder-strewn hills of unmodified drift, with occasional outcrops or of drumlin formation. A. P. M.]

Change of Marking in the Males of a Spider (Pellenes cristatus). The peculiar markings of the male appear in many species of spiders after the moult before the last when they are not more than half grown, and after the last moult these markings become more distinct and deeper in color. In Pellenes cristatus, however, the young male before the last moult has a bright red spot on the front of the head below the eyes which disappears entirely when it becomes adult. I first noticed these spiders in the autumn of $190 \mathrm{I}$ in their silk nests under sticks on the edge of the salt marshes at Ipswich, Mass. In the following spring Mr. G. W. Peckham visited Boston and he and I went on June $I 7$ to the same place at Ipswich where we found again the young males with red faces and with them adult males with black faces and dull gray and drab markings. We thought at the time that the young males were Pellenes caecutus, a common species south of New York in which the face has a similar red spot both in young and adult males. Mr. Peckham afterward identified the black males as Pellenes cristatus supposed to be the same species as Attus cristalus described by Hentz.

In the spring of 1903 I went to the shore earlier in the season and about the first of May found the black males abundant in the dead grass washed up by the tide along the edges of the marsh and with them an occasional young male with a red spot on the face. I took these home alive and one of them soon moulted and came out a black male $P$. cristatus without any trace of the red marking. - J. H. Emerton. 

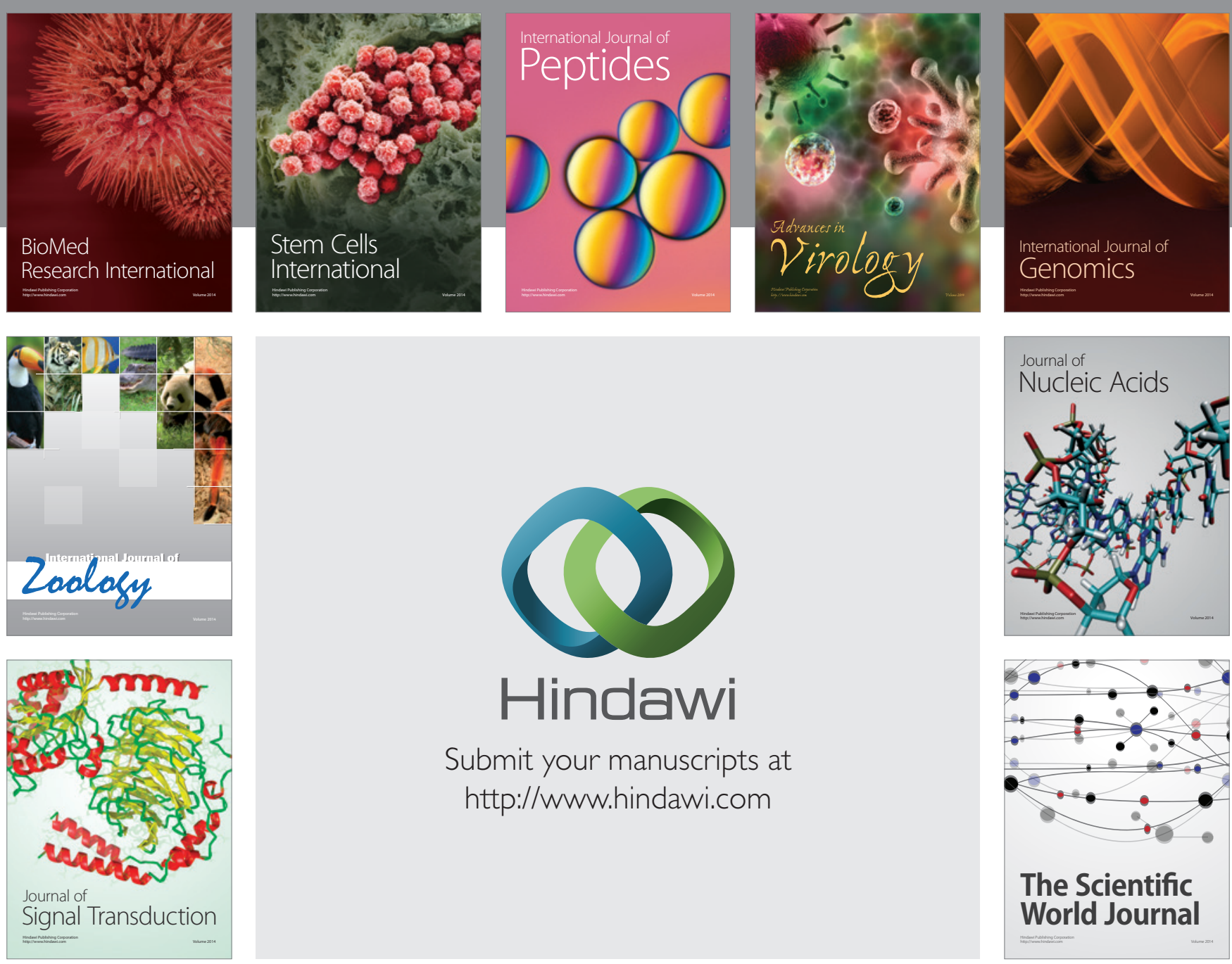

Submit your manuscripts at

http://www.hindawi.com
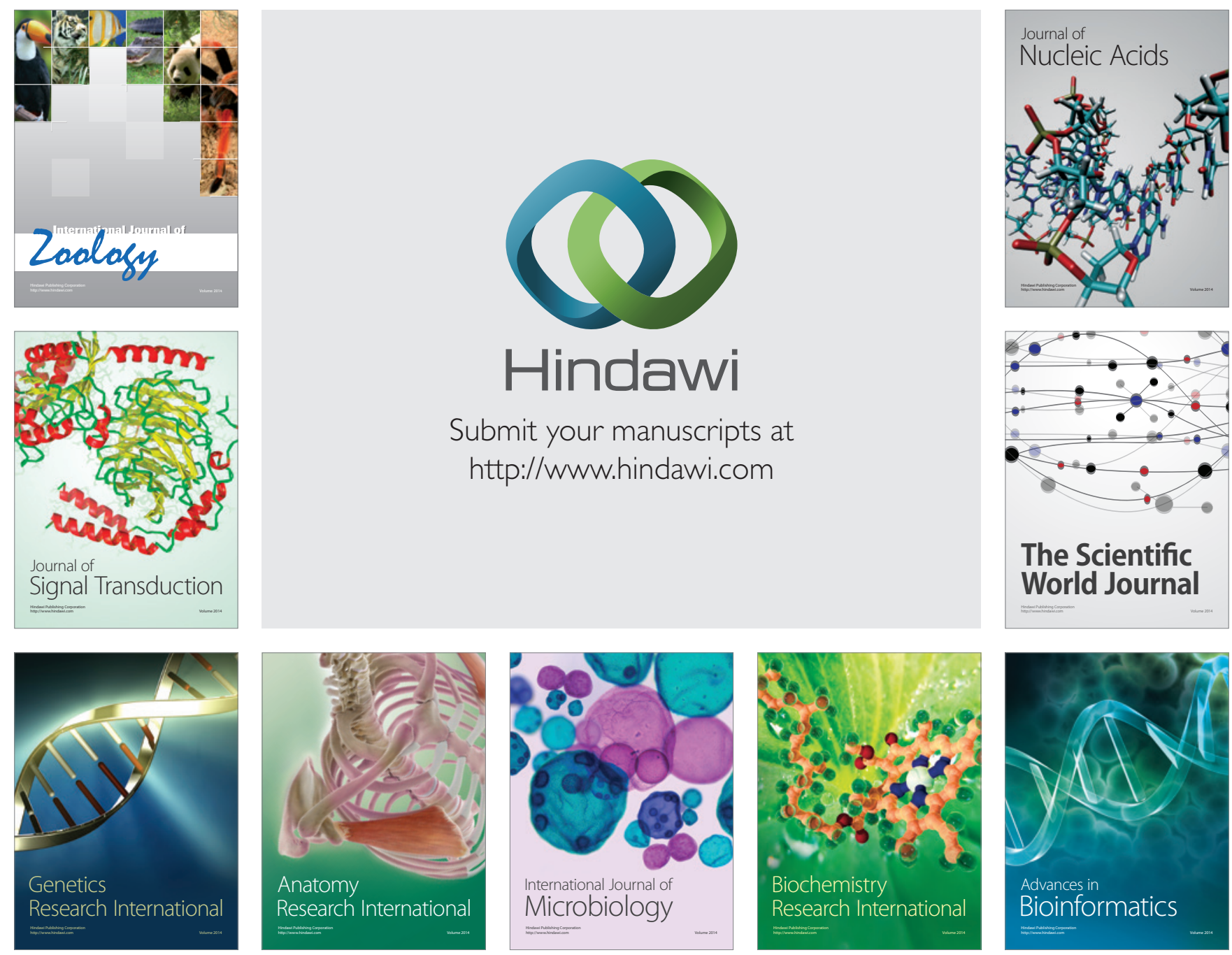

The Scientific World Journal
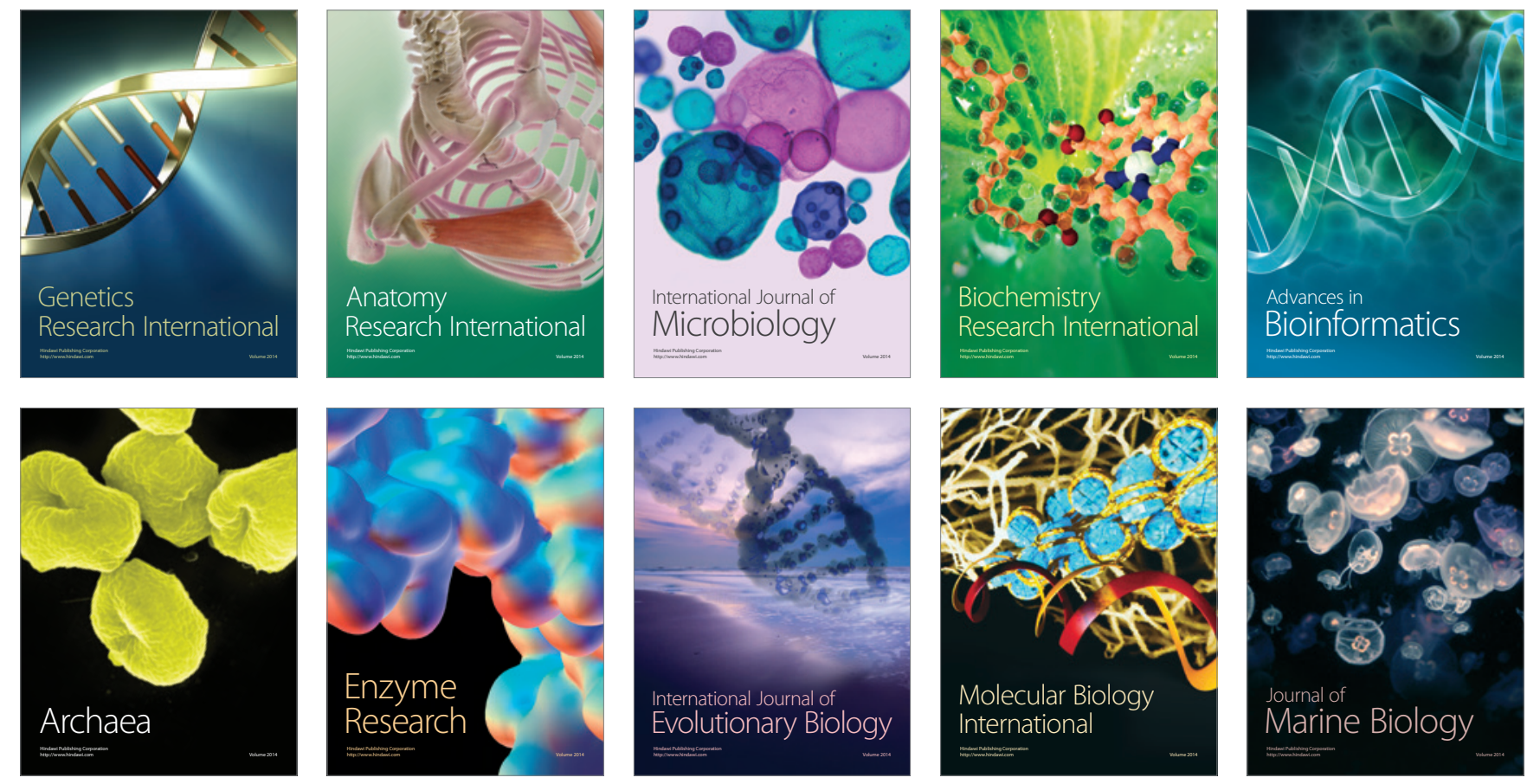